\author{
О.Є. Мавренков ${ }^{1}$, В.І. Улізько ${ }^{1}$, С.В. Матвійчук ${ }^{1}$
}

${ }^{1}$ Державний науково-дослідний інститут авіаиії, Київ

\title{
НАПРЯМИ УДОСКОНАЛЕННЯ МЕТОДИЧНОГО АПАРАТУ ВИБОРУ РАЦІОНАЛЬНИХ ПРОЕКТІВ ПОСТАЧАННЯ АВІАЦІЙНИХ ТРЕНАЖЕРНИХ КОМПЛЕКСІВ
}

\begin{abstract}
За результатами аналізу існуючого методичного апарату порівняльного оцінювання зразків авіаційних тренажерних комплексів обтрунтовано напрями його удосконалення (подальшого розвитку) в системі підтримки прийняття рішення з вибору раціональних проєктів постачання таких комплексів для потреб Збройних Сил України. Для вирімення зазначеного наукового завдання запропоновано використання методів багатокритерійної оптимізачії в системі критеріїв "навчальна ефективність - економічна ефективність - технічний рівень - реалізованість проєкту”. За результатами дослідження представлено структурну блок-схему удосконаленої методики вибору авіаційного тренажерного комплексу, виконано постановку наукових завдань подальших досліджень.
\end{abstract}

Ключові слова: авіаційний тренажерний комплекс, технічний рівень, вартість, ризики, раціональний варіант.

\section{Вступ}

Постановка проблеми. Нестача необхідної кількості авіаційних тренажерних комплексів (АТрК) для забезпечення потреб навчання (підтримання льотних навичок) льотного складу авіації ЗС України, низький рівень їх справності, обумовлений деградацією технічного стану застарілої елементної бази, породжують актуальну проблему оновлення (удосконалення) парку АТрК Збройних Сил (3С) України [1, с. 45].

Аналіз останніх досліджень і публікацій. На сьогодні прийняття рішень в системі створення та закупівлі зразків ОВТ здійснюється на основі вербальних (експертних) методів, ефективність напряму яких залежить від кваліфікації експертів, досвіду та знань особи, що приймає рішення (ОПР). Як показує досвід, такий підхід супроводжується великою ймовірністю прийняття помилкових рішень, це, зокрема, підтверджується систематичним проблемним виконанням прийнятих програм і планів розвитку озброєння та військової техніки 3С України [2, с. 98, 99; 3].

Така ситуація безпосередньо пов'язується 3 відомими недоліками експертних методів, серед яких основними є суб'єктивізм оцінок, обумовлений індивідуальною психологічною реакцію кожного окремого експерта, що знайшло своє відображення у відомих науково-методичних працях, зокрема $[4$, с. $98 ; 5$, с. $4 ; 6$, с. $14 ; 7$, с. $154 ; 8$, с. 35$]$.

При цьому відомі аналітичні методи підтримки прийняття рішень не знайшли широкого застосування, в основному, за причини недосконалості математико-алгоритмічного апарату, що обумовлює обмежені можливості їх програмної реалізації та зручності представлення вихідних даних у інтерфейсі “програма - ОПР” $[9,10]$.
На цей час відомо кілька спроб формалізувати процедуру кількісного оцінювання (вибору) АТрК, що найшли своє відображення у низці наукових праць, наприклад $[11, \quad$ с. 91-97; 12, c. 1-4], та були узагальнені в [13, с. 27-34].

Мета статті - обгрунтування напрямів удосконалення (подальшого розвитку) методичного апарату порівняльного оцінювання зразків авіаційних тренажерних комплексів в системі підтримки прийняття рішення 3 вибору раціональних проєктів постачання таких комплексів для потреб Збройних Сил України.

\section{Виклад основного матеріалу}

Реалізація проєктів розроблення/ модернізації та закупівлі АТрК потребує вирішення науковопрактичної задачі вибору кращих (раціональних, компромісних) варіантів рішень з числа наявних їх альтернатив. При цьому необхідно передбачити комплексне врахування багатьох чинників, що впливають, зокрема, на ефективність вирішення навчальних завдань за призначенням АТрК, технічний рівень (якість) цих комплексів, витрати ресурсів та, що вкрай важливо, на успішність реалізації відповідних проєктів під впливом можливих ризиків [1, с. 47].

На сьогодні в основу відомого методичного апарату порівняльного оцінювання (вибору) АТрК покладається їх співставлення за рівнем технічної досконалості. При цьому технічна досконалість АТрК представляється як інтегральна характеристика, яка, поряд 3 навчальною та економічною ефективністю, включає показник якості АТрК як складної технічної системи - його технічний рівень [13, с. 27].

Структуру складових узагальненого показника технічної досконалості АТрК наведено на рис. 1, $[13$, c. 28$]$ 


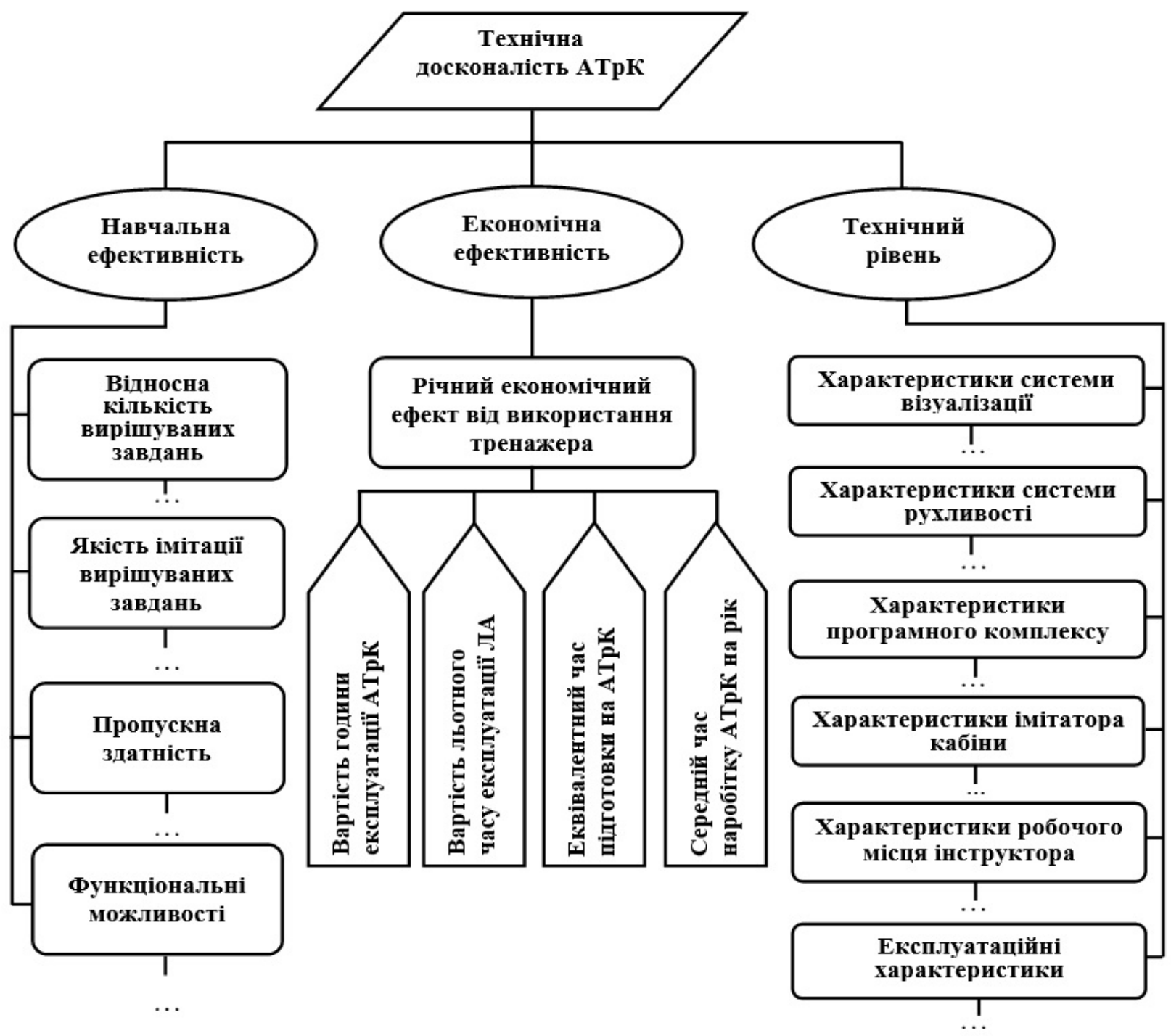

Рис. 1. Структура складових інтегрального показника технічної досконалості авіаційного тренажерного комплексу Джерело: [13, с. 28]

Навчальна ефективність АТрК $\left(E_{H}\right)$ характеризується показниками кількості вирішуваних завдань, що вирішуються на тренажері, якістю імітації цих завдань, пропускною здатністю тренажера як системи навчання, функціональними можливостями щодо автоматизації процесу навчання та контролю якості такого навчання [13, с. 27].

Економічна ефективність АТрК $\left(E_{E}\right)$ характеризується економічним ефектом від його використання, що визначається показниками вартості години експлуатації тренажера, вартості часу експлуатації імітуємого ЛА, часом, необхідним на підготовку льотного складу, часом наробітку тренажера на рік [13, с. 27].

Технічний рівень АТрК визначається характеристиками системи візуалізації, системи рухливості, програмного комплексу, імітатора кабіни екіпажу, робочого місця інструктора та експлуатаційними характеристиками тренажера. Показником технічного рівня приймається коефіцієнт $\left(\kappa_{T P}\right)$, розрахунок якого засновується на математичному апараті кваліметрії, на основі зіставлення визначальних показників технічної досконалості (ПТД) оцінюваного та базового зразків АТрК з урахуванням відносної важливості таких показників [13, с. 28].

Остаточний вибір кращого (раціонального, компромісного) АТрК здійснюється за умовою мінімуму відстані до точки “ідеалу” у нормованому критерійному просторі “навчальна ефективність економічна ефективність - технічний рівень" [13, c. 31-32]

Аналіз методико-алгоритмічного апарату вище представленого підходу до вибору АТрК показав, що існує можливість i доцільність його удосконалення (подальшого розвитку) в частині:

врахування показника реалізованості проєктів постачання (розроблення, модернізації, ліцензійного виробництва, закупівлі тощо) АТрК для потреб Збройних Сил України;

представлення показника економічної ефективності у вигляді вартості життєвого циклу ATpK; 
застосування формальних (математичних) методів визначення відносної важливості (коефіцієнтів вагомості) ПТД замість експертного їх оцінювання.

Показник $R$ реалізовності проєкту постачання АТрК характеризує успішність (ймовірність) виконання проєкту в системі можливих ризиків його реалізації.

Як показує досвід, ігнорування (неврахування) ризиків, що супроводжують процес реалізації складних організаційно-технічних проєктів, до яких належать й проєкти постачання АТрК, може негативно вплинути на очікуваний результат аж до зриву проєкту в цілому.

Оцінювання параметрів усіх ідентифікованих ризиків i розрахунок показника реалізовності проєкту в цілому є основою прийняття ефективних рішень 3 управління ризиками 3 метою успішного виконання проєкту.

Що стосується використання показника економічної ефективності у вигляді, який пропонується в $[13$, с. 27,12$]$, то така його форма носить обмежено інформативний характер, оскільки враховує тільки окремі складові витрат, що не дозволяє коректно використовувати його у системі прийняття рішень щодо вибору АТрК.

Авторами пропонується представлення показника економічної ефективності АТрК у вигляді вартості його життєвого циклу, що дозволить у повній мірі врахувати фінансові витрати, які пов'язані як власне 3 процедурою його розроблення / модернізації, закупівлі, так i подальшою його експлуатацією (утриманням) аж до стадії утилізації.

Що стосується застосування формальних (математичних) методів визначення відносної важливості (коефіцієнтів вагомості) ПТД, то очікується, що це дозволить зменшити вплив суб'єктивного фактору, який властивий експертним методам оцінювання, при визначенні технічного рівня АТрК.

Таким чином вибір кращого (раціонального, компромісного) АТрК доцільно здійснювати в чотиривимірному критерійному просторі “навчальна ефективність - вартість життєвого циклу - технічний рівень - реалізованість проєкту”.

Структурну блок-схему удосконаленої методики вибору АТрК представлено на рис. 2.



Рис. 2. Структурна блок-схема удосконаленої методики вибору авіаційного тренажерного комплексу.

Джерело: розроблено авторами. 
На першому етапі проводиться формування масиву вхідних даних, а саме: визначаються складові навчальної ефективності шляхом експертного оцінювання; складові економічної ефективності на основі воєнно-економічного аналізу; складові технічного рівня, що визначаються за теорією кваліметрії; складові реалізованості проєкту на основі теорії ризиків.

На другому етапі відбувається розрахунок основних показників вибору АТрК, який здійснюється за відповідними методиками.

На третьому етапі здійснюється вибір раціонального зразка АТрК за методом Парето. Якщо серед паретооптимальних зразків залишається два та більше, то вибір серед них раціональних (компромісних) зразків АТрК виконується 3 застосуванням відомих методів звуження паретооптимальної області.

\section{Висновки}

Таким чином, 3 вище наведеного витікають актуальні наукові завдання, що стануть предметом подальших досліджень авторів, а саме - розроблення та апробація методик:

оцінювання реалізованості проєкту постачання АТрК як показника успішності його реалізації в системі можливих ризиків;

оцінювання вартості життєвого циклу АТрК як показника сумарних витрат ресурсів на його придбання та утримання; визначення відносної важливості (коефіцієнтів вагомості) ПТД АТрК на основі формальних (математичних) методів.

\section{Список літератури}

1. Мавренков О.С., Матвійчук С.В. Перспективні шляхи оновлення (удосконалення) авіаційних тренажерів Збройних Сил України. Зб. наук. праць. - К.: ДНДІА. 2020. - Вип.23. - С.44-47.

2. Телюк К.Ф., Сокур В.В. Фінансування національної оборони України // Вісник Університету банківської справи. 2015. № 1 (22). - С.96-102.

3. Стебливский Р. Будет ли выполнен оборонный заказ. URL: https://www.epravda.com.ua/rus/authors/5fecb59c90aa5/ (дата звернення 10.06.2021).

4. Бешелев С.Д., Гурвич Ф.Г. Экспертные оценки. М.: Изд-во “Москва”, 1973. - 163 с.

5. Орлов А.И. Экспертные оценки. - М.: МГТУ им. Н.Э. Баумана, 2002. - 31 с.

6. Назаренко Л.О. Експертиза товарів (Експертиза продовольчих товарів). - К.: Центр учбової літератури, 2014. - 312 с.

7. Бешелев С.Д., Гурвич Ф.Г. Математико-статистические методы экспертных оценок. - М.: Статистика, 1980. - 263 с.

8. Денисова А.Л., Зайцев Е.В. Теория и практика экспертной оценки товаров и услуг. - Тамбов: Изд-во Тамб. гос. техн. ун-та, 2002. - 72 c.

9. Введение в теорию и методы принятия решений / В.Д. Дмитриенко, В.А. Кравец, С.Ю. Леонов. - Х.: ХПИ, 2008. -141 с.

10. Грешилов А.А. Математические методы принятия решений. 2-е изд. М.: МГТУ им. Н.Э.Баумана, 2014. - 647 с.

11. Дудкін І.П. Методика визначення показників воєнно-економічної оцінки ефективності застосування авіаційних тренажерів / Дудкін І.П., Мартинов В.С., Паутинка В.М. Зб. наук. праць. - К.: НЦ ПС ЗСУ, 2004. - Вип.7. - С. 91-97.

12. Самков О.В. Методичні особливості порівняння авіаційних тренажерів / Самков О.В., Корнієнко О.В., Височанський А.С., Качур С.Ю. Наукоємні технології. - К.: НАУ, 2009. - Вип. 2. - С. 1-4.

13. Артюшин Л.М., Мірненко В.І., Мавренков О.С. Методика оцінювання технічної досконалості авіаційних тренажерних комплексів. Зб. наук. праць. - К.: ДНДІА, 2016. - Вип.19. - С.27-34.

\section{Відомості про авторів:}

\section{Мавренков Олексій Сфремович \\ доктор технічних наук \\ старший науковий співробітник \\ начальник науково-дослідної лабораторії \\ Державного науково-дослідного інституту авіації, \\ Київ, Україна \\ https://orcid.org/0000-0002-6578-4833}

\section{Улізько Вячеслав Іванович}

старший науковий співробітник

Державного науково-дослідного інституту авіації,

Київ, Україна

https://orcid.org/0000-0003-4553-7752

\section{Information about the authors:}

\section{Oleksii Mavrenkov}

Doctor of Technical Sciences

Senior Researcher

Head of Research Laboratory

of State Research Institute of Aviation,

Kyiv, Ukraine

https://orcid.org/0000-0002-6578-4833

\section{Viacheslav Ulizko}

Senior Researcher

of State Research Institute of Aviation, Kyiv, Ukraine

https://orcid.org/0000-0003-4553-7752 


\section{Матвійчук Сергій Віталійович}

ад'юнкт

Державного науково-дослідного інституту авіації, Київ, Україна

https://orcid.org/0000-0003-2774-0378

\section{Serhii Matviichuk}

$\mathrm{PhD}$ student

of State Research Institute of Aviation, Kyiv, Ukraine

https://orcid.org/0000-0003-2774-0378

\title{
DIRECTIONS OF IMPROVEMENT OF METHODOLOGICAL AND ALGORITHMIC APPARATUS IN THE SYSTEM OF SELECTION OF RATIONAL PROJECTS OF SUPPLY OF AVIATION EXERCISE COMPLEXES
}

\author{
O. Mavrenkov, V. Ulizko, S. Matviichuk
}

For the results of analysis of existent methodical vehicle of comparative evaluation of standards of aviation trainer complexes reasonably directions of his improvement (further development) in the system of support of decision-making on the choice of rational projects supply of such complexes for the necessities of the Armed Forces of Ukraine. For the decision of the marked scientific task the use of methods of multicriterion optimization is offered in the system of criteria "educational efficiency is economic efficiency - technical level - realized of project". The analysis of the known methodological apparatus of comparative evaluation of samples of aviation training complexes showed that there is a possibility and expediency of its improvement (further development) in part: taking into account the implementation of projects of supply (development, modernization, licensing, procurement, etc.) of aviation training complexes Forces of Ukraine; presentation of the indicator of economic efficiency in the form of cost of a life cycle of aviation training complexes; application of formal (mathematical) methods for determining the relative importance (weighting factors) of technical excellence indicators instead of their expert evaluation.

According to the results of research the structural flow-chart of the improved methodology of choice of aviation trainer complex is presented, the statement of scientific tasks of further researches is executed, namely development and approbation methodologies: evaluation of realized of project supply of aviation trainer complexes as index of success his realization in the system of possible risks; evaluation of cost of life cycle of aviation trainer complex as index of total charges of resources on his acquisition and maintenance; determination of relative importance (coefficients of validity) of indexes of technical perfection of aviation trainer complex is on the basis of formal (mathematical) methods.

Keywords: aviation trainer complex, technical level, cost, risks, rational variant. 